\title{
Evaluation of the Anticorrosive Properties of Environmental Friendly Inorganic Corrosion Inhibitors Pigments
}

\author{
Adriana O. S. Leite ${ }^{a}$, Walney S. Araújo ${ }^{a}$, Isabel C.P. Margarit ${ }^{b}$, Adriana N. Correia $^{a}$ \\ and Pedro de Lima-Neto ${ }^{*, a}$ \\ ${ }^{a}$ Departamento de Química Analítica e Físico-Química, Universidade Federal do Ceará, CP 6035, \\ 60455-970 Fortaleza - CE, Brazil \\ ${ }^{b}$ Departamento de Processos Inorgânicos, Escola de Química, Universidade Federal do Rio de Janeiro, \\ 21000-000 Rio de Janeiro - RJ, Brazil
}

\begin{abstract}
Neste trabalho foram estudadas as propriedades anticorrosivas de cinco pigmentos inorgânicos comerciais considerados ecologicamente corretos: fosfato de zinco (ZP), molibdato de zinco (ZM), molibdato de zinco e cálcio (ZCM), fosforomolibdato de zinco (ZPM) e fosforomolibdato de zinco e cálcio (ZCPM). Amostras de aço AISI 1010 foram imersas em solução aquosa de $\mathrm{NaCl} 10^{-2} \mathrm{~mol}$ $\mathrm{dm}^{-3}$ saturada com um dos pigmentos, seguido de medidas de perda de massa, monitoramento do potencial de circuito aberto com o tempo de imersão e polarização linear potenciodinâmica a $1 \mathrm{mV} \mathrm{s}$ ${ }^{1}$. Os produtos de corrosão foram caracterizados por Microscopia Eletrônica de Varredura, Energia Dispersiva da raios-X e Difração de raios-X. Todos os pigmentos inibiram a corrosão do aço. Os filmes formados na superfície protegem o aço contra corrosão. Os resultados sugerem efeito sinérgico entre os compostos de fosfato e molibdato nos pigmentos a base de fosforomolibdato. Os pigmentos ZMP e ZCPM diminuíram a taxa de corrosão por um fator de 2,15 e 3,50, respectivamente.
\end{abstract}

Anticorrosive properties of the following environmental friendly inorganic pigments were evaluated: zinc phosphate (ZP), zinc molybdate (ZM), zinc calcium molybdate (ZCM), zinc phosphomolybdate (ZPM) and zinc calcium phosphomolybdate (ZCPM). AISI 1010 steel samples were immersed in $10^{-2} \mathrm{~mol} \mathrm{dm}^{-3} \mathrm{NaCl}$ aqueous solution saturated with one of the pigments, followed by mass loss measurements, by monitoring the open circuit potential with immersion time and by potentiodynamic linear polarization at $1 \mathrm{mV} \mathrm{s}^{-1}$. The corrosion products on the steel surface were characterized by Scanning Electron Microscopy, Energy Dispersive X-ray and X-rays Diffraction analyses. All the pigments inhibited the corrosion of steel. The films formed on the steel surface protect the substrate against corrosion. The results suggest a synergic effect of phosphate and molybdate compounds in the phosphomolybdate-based pigments, improving the corrosion resistance of steel. The ZMP and ZCPM decreased the corrosion rate by a factor of 2.15 and 3.50, respectively.

Keywords: steel, corrosion, anticorrosive pigments, mass loss, electrochemical tests, surface analysis

\section{Introduction}

It is widely recognized that organic coatings have many technical and economic advantages for metal protection against corrosion. The protection mechanism can be associated with barrier effects and action of anticorrosive pigments present in the coating. However, environmental considerations are limiting the use of organic solvent-borne paints because it contributes to atmospheric pollution and causes health problems. In addition, the toxic nature of the more traditional anticorrosive pigments, such as red lead and zinc chromate,

* e-mail: pln@ufc.br has stimulated researches for changes in the formulation of paints. At present, it is raising the interest in the new generation of anticorrosive pigments, called "environmental friendly", which have been proposed to replace the toxic anticorrosive pigments in the paint formulations. ${ }^{1-12}$

Phosphate was the first proposed alternative to replace zinc chromate in paint formulation. ${ }^{1}$ However, the results presented in the literature are not conclusive about the efficiency of primers pigmented with phosphate, since these coatings presented a poor protection in accelerated test but a good performance in outdoor long exposure tests and in industrial environments. ${ }^{1,4,6}$ 
Molybdate is another inorganic anion used as safe alternative, because despite molybdenum is localized in the chromium group in the periodic table (group VI), seeming to have similar chemical properties to chromium, it presents non-toxicity intake, ${ }^{13}$ low toxicity to aquatic species ${ }^{14}$ and, as molybdate is a white pigment, it can be used in white or tintable primers, top coats, and direct-to-metal systems. ${ }^{1}$

Phosphomolybdates are the newest generation of the safe pigments, which combine the corrosion-inhibiting properties of phosphate and molybdate compounds. The commercial phosphomolybdates products are the zinc phosphomolybdate and zinc calcium phosphomolybdate. However, despite of the success of the phosphomolybdates pigments to improve the corrosion resistance of primers, ${ }^{1,3,4,8}$ little attention is given in the literature about the understanding of the anticorrosive properties of these pigments in aqueous medium.

Thus, this work presents a systematic investigation of corrosion-inhibiting properties of five commercial "environmental friendly" inhibitor pigments in aerated $10^{-2}$ mol dm${ }^{-3} \mathrm{NaCl}$ aqueous. The evaluation was carried out by mass loss measurement, by electrochemical techniques, by Scanning Electron Microscopy (SEM), by Energy Dispersive $\mathrm{X}$-ray (EDX) analysis and X-ray Diffraction (XRD) techniques, aiming to improve the understanding of the inhibiting corrosion properties of these pigments. The studied pigments were: zinc phosphate (ZP), zinc molybdate (ZM), zinc calcium molybdate (ZCM), zinc phosphomolybdate (ZPM) and zinc calcium phosphomolybdate (ZCPM).

\section{Experimental}

\section{Corrosion tests}

All the studied pigments were supplied by Moly-White Pigments Group. The solubility of the pigments in aqueous media is very low, thus, in order to assess the corrosion inhibiting properties of these pigments, saturated solution of each pigment containing $10^{-2} \mathrm{~mol} \mathrm{dm}^{-3} \mathrm{NaCl}$ were prepared following by immersion of AISI 1010 steel in each solution test. Physico-chemical characterization of the saturated pigment solution is presented in Table 1. Metal ionic composition of the working solutions were determined by atomic emission ICP-OES technique using a Perkin Elmer Optma 4300 spectrometer and the phosphorus content by molecular absorption using a UVVIS SHIMADZU, model UV-1601 PC.

The working panels were dipped in the working solutions in vertical position exposing an area of $32 \mathrm{~cm}^{2}$ and their open circuit potentials were monitored. Saturated calomel electrode was used as reference in all electrochemical measurements. The corrosion rate $\left(\mathrm{v}_{\text {cor }}\right)$ was calculated using the ASTM G1-81 Standard Practice.

The cathodic and anodic behaviors of the AISI 1010 steel in each working solution were assessed through potentiodynamic linear polarization (PLP) technique at 1 $\mathrm{mV} \mathrm{s}^{-1}$, at room temperature, and obtained after $2 \mathrm{~h}$ of exposure time. The working electrode was constructed using a disc of AISI 1010 steel embedded in epoxy resin leaving a working area of $0.785 \mathrm{~cm}^{2}$. Prior each experiment, the working electrode was polished with grid 400 emery paper, degreased with alcohol and cleaning in water. Platinum foil was used as auxiliary electrode. The PLP experiments were performed using a potentiostat/ galvanostat AUTOLAB PGSTAT 30, linked with a PC computer and controlled by the GPES 4.9 for acquisition and analysis of the electrochemical data.

Table 1. $\mathrm{pH}$ and ionic concentration of the working solutions

\begin{tabular}{|c|c|c|c|c|c|}
\hline \multirow{2}{*}{$\begin{array}{l}\text { Working } \\
\text { solutions }\end{array}$} & \multirow[t]{2}{*}{$\mathrm{pH}$} & \multicolumn{4}{|c|}{ Ionic concentration $\left(\mathrm{mg} \mathrm{dm}^{-3}\right)$} \\
\hline & & $\mathrm{Ca}^{2+}$ & $\mathrm{Zn}^{2+}$ & $\mathrm{MoO}_{4}^{2-}$ & $\mathrm{PO}_{4}^{3-}$ \\
\hline $\mathrm{NaCl}+\mathrm{ZP}$ & 7.12 & & 37 & & 104 \\
\hline $\mathrm{NaCl}+\mathrm{ZM}$ & 7.12 & & 171 & 395 & \\
\hline $\mathrm{NaCl}+\mathrm{ZCM}$ & 8.15 & 115 & 149 & 295 & \\
\hline $\mathrm{NaCl}+\mathrm{ZMP}$ & 7.28 & & 185 & 175 & 524 \\
\hline $\mathrm{NaCl}+\mathrm{ZCPM}$ & 7.65 & 81 & 97 & 190 & 322 \\
\hline
\end{tabular}

Physico-chemical characterization of the protective film on the steel surface

The morphology of the protective films on the steel surface after the end of immersion test was examined by scanning electron microscopy (SEM) technique using a Philips XL-30 scanning electron microscope. The identification of the chemical elements was carried out by EDX analysis using a Link Analytical QX-2000 attached to the SEM apparatus. The chemical compounds presenting on the steel surface were identified by X-ray diffraction technique using a Phillips X' Pert-Pro using a $\mathrm{Cu} \mathrm{K}_{\alpha}$ at 40 $\mathrm{KV}$ and $40 \mathrm{~mA}$ with an incident angle of 2 degrees. The main peaks observed in the diffractograms were compared with XRD data from JCPDS (Joint Committee of Powder Diffraction Standards).

\section{Results and Discussion}

\section{Physico-chemical characterization of the saturated solutions}

Table 1 shows that $\mathrm{pH}$ of saturated solution of $\mathrm{ZP}, \mathrm{ZM}$, $\mathrm{ZMP}$ and ZCPM are close to neutrality while the ZCM is 
slightly alkaline. According Pourbaix diagram, ${ }^{15,16}$ the passivation of steel can be considered begins at $\mathrm{pH}$ higher than 8 for aerated solution, and these $\mathrm{pH}$ values suggest that the acid-base characteristics of the pigments do not significantly contribute to passivation of the steel in aqueous medium.

This table also shows that phosphomolybdate-based pigments present the highest total concentration of soluble $\mathrm{PO}_{4}^{3-}$ and $\mathrm{MoO}_{4}{ }^{2-}$ in saturated solution, which can improve the corrosion resistance of steel, since these ions are well known as inhibitors of the dissolution of steel and other metals and alloys in aqueous medium. ${ }^{17}$ Additionally, the presence of soluble $\mathrm{Ca}^{2+}$ in the corresponding saturated solutions also can improve the anticorrosive protection of steel because this ion is known as a natural inhibitor of the oxygen reduction reaction in aqueous medium, ${ }^{17}$ which is the cathodic reaction of the corrosion process in neutral medium.

Table 2. Corrosion rate and electrochemical parameters derived from polarization curves

\begin{tabular}{lcccc}
\hline $\begin{array}{l}\text { Working } \\
\text { Solutions }\end{array}$ & $\begin{array}{c}\mathrm{v}_{\text {cor }} \\
\left(\mathrm{mm} \mathrm{y}^{-1}\right)\end{array}$ & $\begin{array}{c}\mathrm{E}_{\text {cor }} \\
(\mathrm{mV} \text { vs. SCE })\end{array}$ & $\begin{array}{c}\mathrm{Rp} \\
\left(\mathrm{ohm} \mathrm{cm}^{2}\right)\end{array}$ & $\%$ IP \\
\hline $\mathrm{NaCl}$ & 1.06 & -0.648 & 119 & 0 \\
$\mathrm{NaCl}+\mathrm{ZM}$ & 1.00 & -0.558 & 199 & 67 \\
$\mathrm{NaCl}+\mathrm{ZP}$ & 0.57 & -0.480 & 461 & 287 \\
$\mathrm{NaCl}+\mathrm{ZCM}$ & 0.55 & -0.501 & 491 & 313 \\
$\mathrm{NaCl}+\mathrm{ZMP}$ & 0.49 & -0.508 & 618 & 420 \\
$\mathrm{NaCl}+\mathrm{ZCPM}$ & 0.30 & -0.473 & 540 & 354 \\
\hline
\end{tabular}

\section{Mass loss}

The $\mathrm{v}_{\text {cor }}$ of the AISI 1010 samples in the corresponding working solutions, calculated according ASTMG1-81, are shown in Table 2. This table shows that all pigments inhibit the corrosion of steel in the aerated $\mathrm{NaCl}$ aqueous solution. $\mathrm{ZP}$ is a more efficient corrosion inhibitor than ZM. The worst anticorrosive behavior presented by $\mathrm{ZM}$ pigment are in agreement with the results presented by Aramaki.? This author showed that $\mathrm{MoO}_{4}^{2-}$ is not an efficient corrosion inhibitor of $\mathrm{Zn}$ in aqueous medium containing chloride ions because $\mathrm{MoO}_{4}^{2-}$ did not inhibited pitting corrosion on the $\mathrm{Zn}$ surface.

On the other hand, the addition of calcium improves the efficiency of molybdate-based pigment. Probably, this improvement in the corrosion inhibition of the ZCM pigment is related to the presence of calcium cation in solution. The lowest $\mathrm{v}_{\text {cor }}$ presented by phosphomolybdatebased pigments it is a clear indicative of a synergic effect of phosphate and molybdate ions. Additionally, ZCPM was the best corrosion inhibitor pigment, decreasing $\mathrm{V}_{\text {cor }}$ by a factor of 3.5, suggesting again the influence of the calcium ions in the inhibitive properties of the pigment in aqueous medium. The best behavior presented by the ZCPM pigment is probably related to its highest ion concentration generated by this pigment in aqueous medium, which can improve the corrosion protection of steel when the epoxy film presents defects that make possible permeation of water through the coating.

Table 3. Chemical compounds present in the steel surface after the end of immersion tests identified by XRD analyses

\begin{tabular}{lcccccc}
\hline $\begin{array}{l}\text { Working } \\
\text { solutions }\end{array}$ & $\mathrm{Fe}_{2} \mathrm{O}_{3}$ & $\mathrm{ZnO}$ & $\mathrm{ZnMoO}_{4}$ & $\mathrm{CaMoO}_{4}$ & $\mathrm{Zn}_{3}\left(\mathrm{PO}_{4}\right)_{2}$ & $\mathrm{Fe}_{3}\left(\mathrm{PO}_{4}\right)_{2}$ \\
\hline $\mathrm{NaCl}$ & $\mathrm{X}$ & & & & & \\
$\mathrm{NaCl}+\mathrm{ZP}$ & $\mathrm{X}$ & $\mathrm{X}$ & & & $\mathrm{X}$ & $\mathrm{X}$ \\
$\mathrm{NaCl}+\mathrm{ZM}$ & $\mathrm{X}$ & $\mathrm{X}$ & $\mathrm{X}$ & & & \\
$\mathrm{NaCl}+\mathrm{ZCM}$ & $\mathrm{X}$ & $\mathrm{X}$ & $\mathrm{X}$ & $\mathrm{X}$ & & \\
$\mathrm{NaCl}+\mathrm{ZMP}$ & $\mathrm{X}$ & $\mathrm{X}$ & $\mathrm{X}$ & & $\mathrm{X}$ & $\mathrm{X}$ \\
$\mathrm{NaCl}+\mathrm{ZCPM}$ & $\mathrm{X}$ & $\mathrm{X}$ & $\mathrm{X}$ & $\mathrm{X}$ & $\mathrm{X}$ & $\mathrm{X}$ \\
\hline
\end{tabular}

\section{Physicochemical characterization of the films}

The surface morphologies of the films presenting on the steel surface after the end of immersion tests are shown in Figure 1-3, which also show the corresponding EDX spectra. The corresponding corrosion products, identified by XRD analyses, are listed in Table 3.

The micrograph of the sample immersed in $\mathrm{NaCl}$ solution without pigments (Figure 1A) revealed a granular corrosion product randomly distributed on the steel surface. $\mathrm{Fe}$ and $\mathrm{O}$ were detected by EDX analysis. Here and in all the studied cases, the Fe signal observed in the EDX spectra can be derived both from the underlying iron substrate and from the film. Table 3 shows that $\mathrm{Fe}_{3} \mathrm{O}_{4}$ (hematite) was the unique corrosion product presents on the steel surface immersed in $\mathrm{NaCl}$ solution without inhibitor, which is widely known to be a non-protective film of iron and steel against corrosion in presence of chloride ions. ${ }^{16-18}$

In the case of steel removed from ZP solutions (Figure $1 \mathrm{~B})$, the surface layer is granular, uniform and rather compact. $\mathrm{Zn}, \mathrm{Fe}, \mathrm{P}$ and $\mathrm{O}$ elements were qualitatively identified by EDX analysis. $\mathrm{Fe}_{2} \mathrm{O}_{3}, \mathrm{ZnO}, \mathrm{Zn}_{3}\left(\mathrm{PO}_{4}\right)_{2}$ and $\mathrm{Fe}_{3}\left(\mathrm{PO}_{4}\right)_{2}$ were identified by XRD analyses as being the components of the protective layer. Deyá et al. ${ }^{8}$ characterized the film presents on the steel surface after $24 \mathrm{~h}$ of immersion in $0.025 \mathrm{~mol}$ $\mathrm{dm}^{-3}$ sodium perchlorate solutions, at $\mathrm{pH}$ closely to neutrality, and containing different types of inorganic phosphate anions by SEM and EDX techniques. These authors did not detect phosphorous compounds on the film composition and pointed out that zinc hydroxide and iron oxide were the main components of the protective layer. 

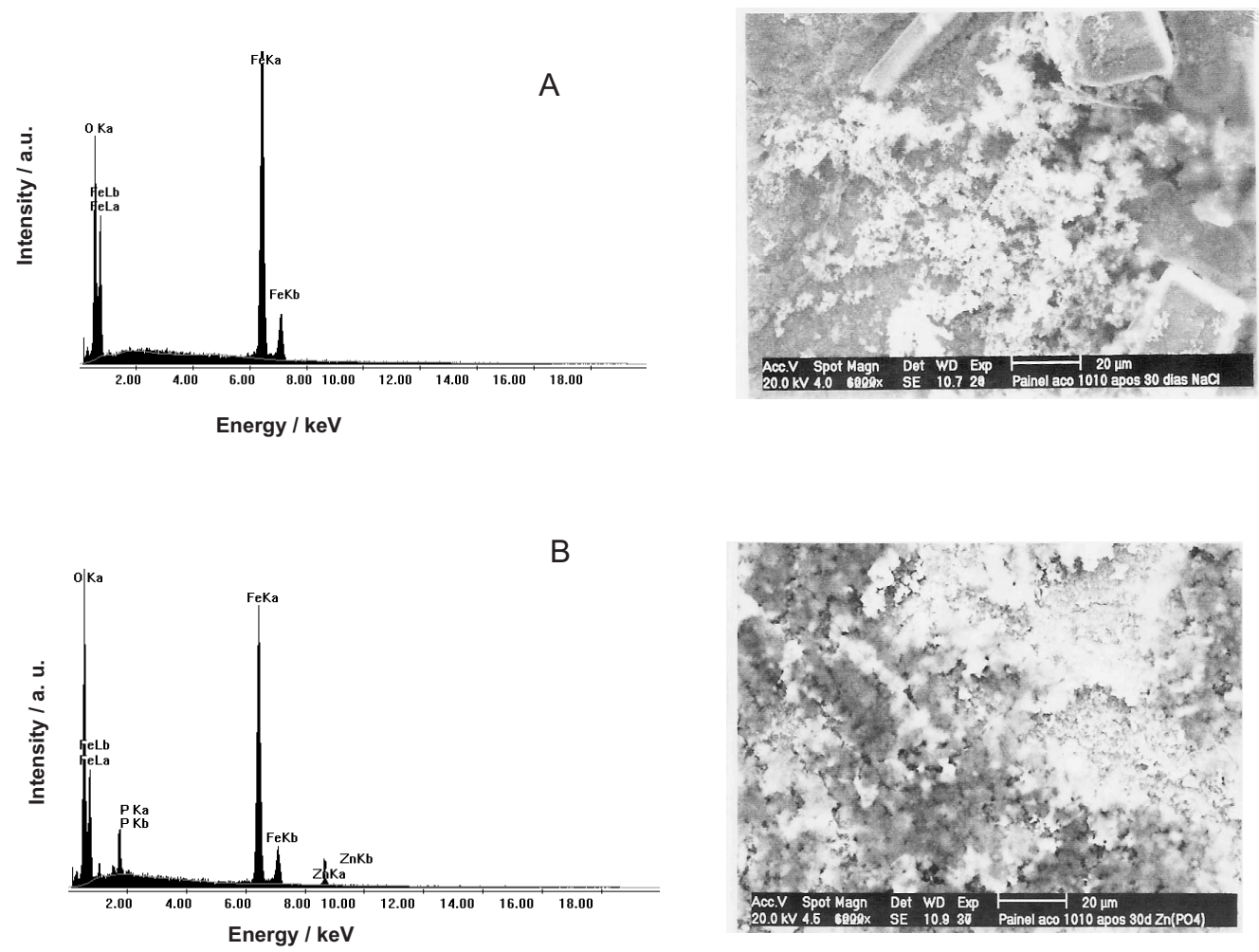

Figure 1. SEM micrographs and EDX spectra of the corrosion product on steel surface after the end of immersion test in $10^{-2} \mathrm{~mol} \mathrm{dm}^{-3} \mathrm{NaCl}$ without pigment (A) and saturated with ZP pigment (B).
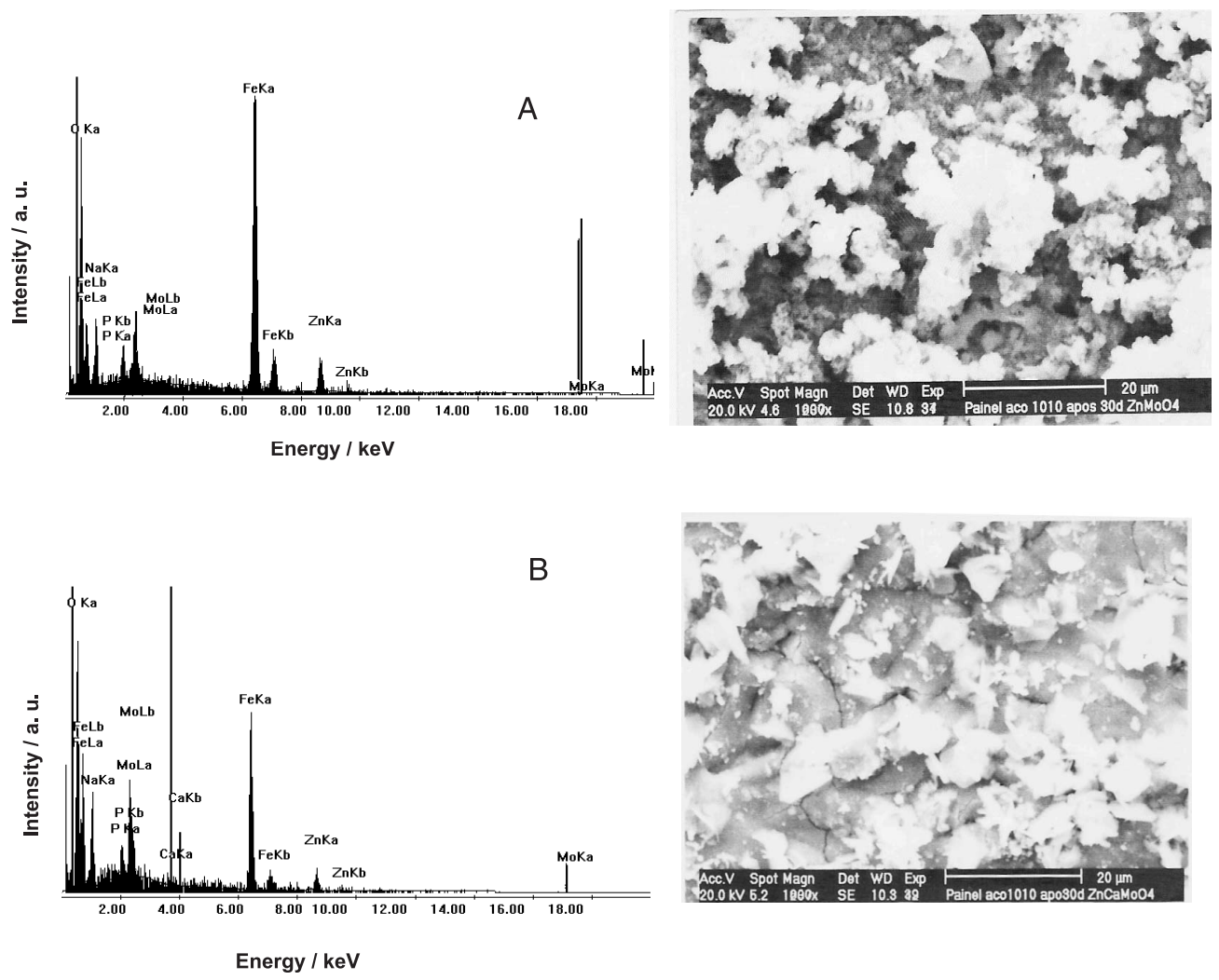

Figure 2. SEM micrographs and EDX spectra of the corrosion product on steel surface after the end of immersion test in $10^{-2} \mathrm{~mol} \mathrm{dm}^{-3} \mathrm{NaCl}$ saturated with ZM (A) and ZCM (B) pigments. 
A
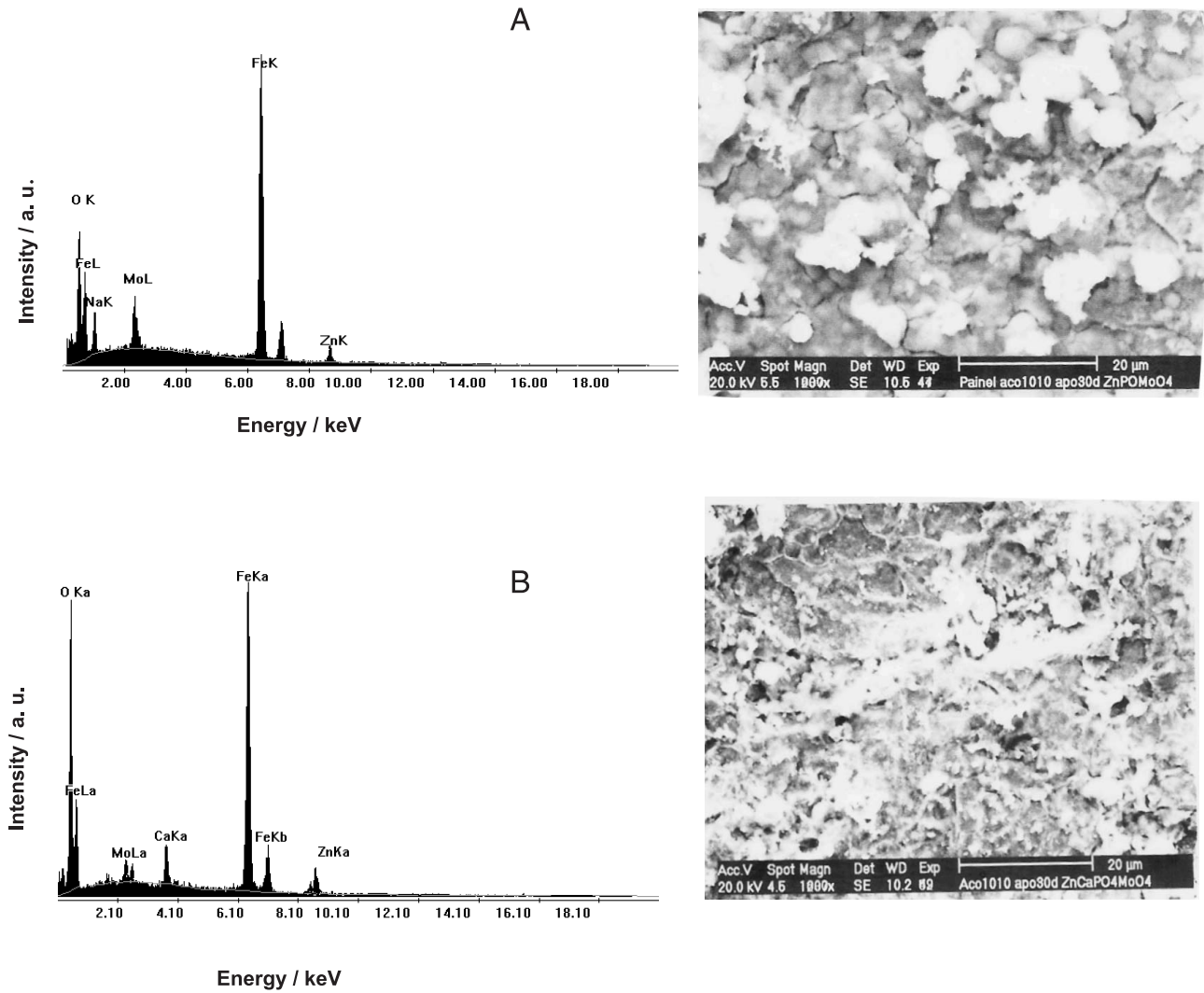

Figure 3. SEM micrographs and EDX spectra of the corrosion product on steel surface after the end of immersion test in $10^{-2} \mathrm{~mol} \mathrm{dm}^{-3} \mathrm{NaCl}$ saturated with ZMP (A) and ZCPM (B) pigments.

The surface layer generated from ZM pigment solution (Figure 2A) is also rather porous and uniform with some globular formation on top. $\mathrm{Fe}, \mathrm{Zn}, \mathrm{Mo}$ and $\mathrm{O}$ were detected by EDX. The XRD made possible to identify the $\mathrm{Fe}_{2} \mathrm{O}_{3}$, $\mathrm{ZnO}$ and $\mathrm{ZnMoO}_{4}$ as components of the surface film.

The morphology of the film obtained from ZCM solution (Figure 2B) is also compact with cracks and some globular crystals on top. $\mathrm{Ca}, \mathrm{Mo}, \mathrm{Fe}$ and $\mathrm{Zn}$ elements were identified on film composition by EDX analyses. $\mathrm{Fe}_{2} \mathrm{O}_{3}$, $\mathrm{ZnO}, \mathrm{ZnMoO}_{4}$ and $\mathrm{CaMoO}_{4}$ compounds were identified by XRD analyses.

The layer originated from ZMP solution is compact (Figure $3 \mathrm{~A}$ ) presenting $\mathrm{Zn}, \mathrm{Mo}, \mathrm{P}$ and Fe in its composition. According to XRD analyses, this film is constituted by $\mathrm{Fe}_{2} \mathrm{O}_{3}, \mathrm{ZnO}, \mathrm{ZnMoO}_{4}, \mathrm{Zn}_{3}\left(\mathrm{PO}_{4}\right)_{2}$ and $\mathrm{Fe}_{3}\left(\mathrm{PO}_{4}\right)_{2}$. Finally, the layer from ZCPM solution is also compact (Figure $3 \mathrm{~B}$ ) and the $\mathrm{Ca}, \mathrm{Zn}, \mathrm{Mo}, \mathrm{P}$ Fe and $\mathrm{O}$ were identified by EDX. $\mathrm{XRD}$ analyses showed that this film is constituted by $\mathrm{Fe}_{2} \mathrm{O}_{3}$, $\mathrm{ZnO}, \mathrm{ZnMoO}_{4}, \mathrm{CaMoO}_{4}, \mathrm{Zn}_{3}\left(\mathrm{PO}_{4}\right)_{2}$ and $\mathrm{Fe}_{3}\left(\mathrm{PO}_{4}\right)_{2}$.

\section{Electrochemical measurements}

Figure 4 shows the evolution of the $\mathrm{E}_{\mathrm{oc}}$ with immersion time of steel in the all working solutions. As can be observed, the values of $\mathrm{E}_{\mathrm{oc}}$ are always decreasing for the samples immersed in $\mathrm{NaCl}$ solution without pigment. In the case of steel immersed in the saturated pigment solutions, the $\mathrm{E}_{\mathrm{oc}}$ values initially decrease until to reach a minimum, followed by an increase until to reach a plateau. Additionally, this figure also shows that the steels immersed

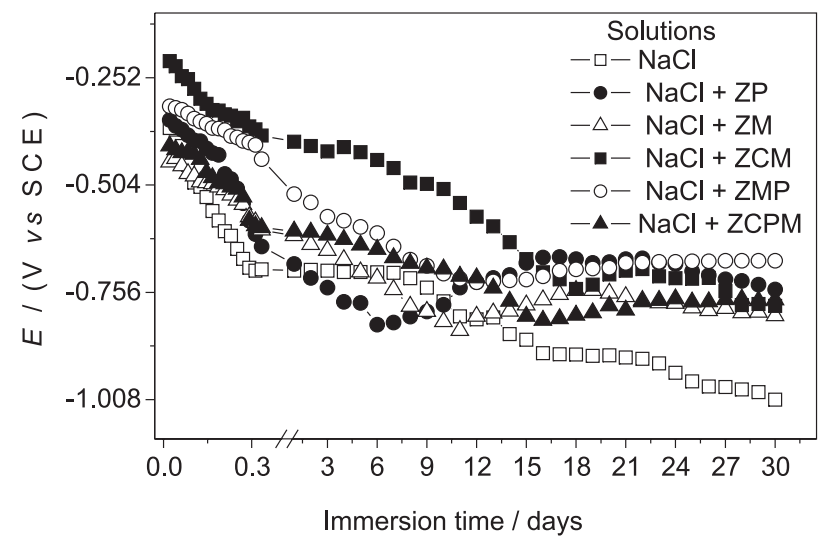

Figure 4. Time dependence of the open circuit potential of AISI 1010 steel immersed in $10^{-2} \mathrm{~mol} \mathrm{dm}^{-3} \mathrm{NaCl}$ aqueous solutions saturated with the studied pigments. 
in pigment solutions present the $\mathrm{E}_{\mathrm{oc}}$ more positive than that immersed in $\mathrm{NaCl}$ solution without pigment, suggesting that all pigments inhibit the anodic reaction.

The influence of the pigments on the cathodic and anodic reactions was analyzed through the potentiodynamic polarization curves and the plots are shown in Figure 5. As can be observed, all the curves obtained from the solutions containing the pigments show cathodic and anodic current densities lesser than those obtained from the solution without pigment. Thus, all the studied pigments can be classified as mixed, because inhibit the oxygen reduction reaction (cathodic reaction) and steel oxidation (anodic reaction). These curves also suggest that steel is susceptible to generalized corrosion in all the working solutions because active-passive state is not observed in this plot.

Additionally, among the inhibitors, ZM presents the highest cathodic and anodic current densities. On the cathodic branch, the others inhibitors present very close cathodic current densities values, while in the anodic one of the polarization curves, the phosphomolybdate-based pigments have the lesser anodic current density. From the physico chemical characterization, the anodic inhibition of the pigments can be explained by the formation of the protective films on steel surface, while the different behaviors of the anodic curves can be attributed to the nature of these protective films.

The electrochemical parameters derived from the polarization curves are listed in Table 2. This table shows that the corrosion potentials $\left(E_{\text {cor }}\right)$ obtained from the saturated pigment solutions were shifted towards more positive values with respect to solution without pigment, being the phosphomolybdate-based pigments which presented the more positive values.

Table 2 also list the values of relative inhibition power, which is used to evaluate the effect of each pigment in the corrosion of steel and were calculated using the equation $1::^{10}$

$\% I P=\left(\frac{R_{p}-R_{p}^{0}}{R_{p}^{0}}\right) 100$

In this equation, \% IP is the inhibition power of the evaluated pigment; $\mathrm{R}_{\mathrm{p}}$ and $\mathrm{R}_{\mathrm{p}}{ }^{0}$ are the polarization resistance of the steel derived from polarization curves in the presence and absence of the pigments, respectively.

A good correlation between the $\mathrm{v}_{\text {cor }}$ and the $\%$ IP can be observed in this table. Thus, among the pigments, $\mathrm{ZM}$ is the worst, being in agreement with the results presented by Aramaki, ${ }^{7}$ which showed that $\mathrm{PO}_{4}^{3-}$ is a more efficient inhibitor than $\mathrm{MoO}_{4}^{2-}$ for zinc corrosion in $\mathrm{NaCl}$ solution, and the best are the phosphomolybdate-based pigments.

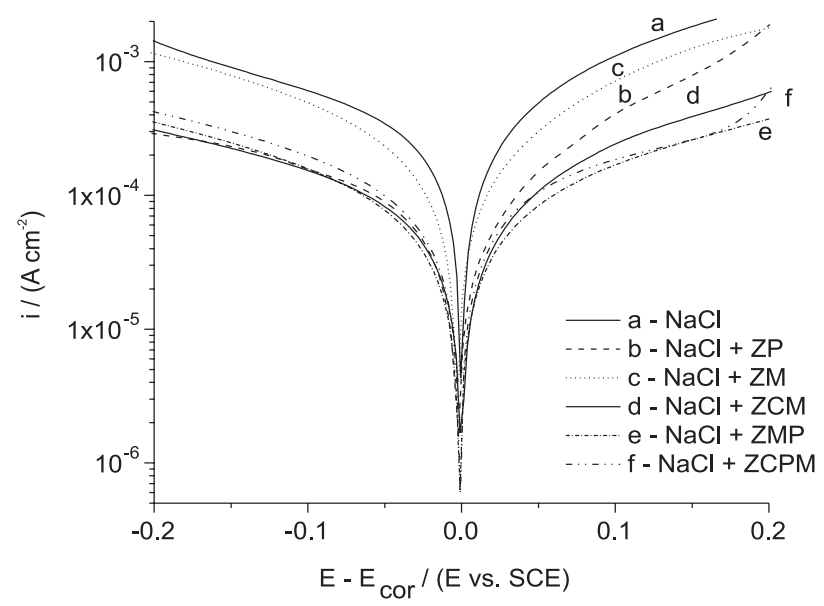

Figure 5. Potentiodynamic polarization curves obtained for the AISI 1010 steel at $1 \mathrm{mV} \mathrm{s}^{-1}$ in $10^{-2} \mathrm{~mol} \mathrm{dm}^{-3} \mathrm{NaCl}$ aqueous solutions saturated with the corresponding pigments.

\section{Conclusions}

All the commercial pigments present inhibition properties against corrosion of steel in aqueous medium containing chloride ions, inhibiting both the cathodic and anodic reactions. The films formed on the surface of steel immersed in the pigment solution protect the substrate against corrosion acting as a barrier layer, but do not avoid the corrosion. Additionally, the obtained results suggest a synergic effect of phosphate and molybdate compounds in the phosphomolybdate-based pigments improving the corrosion resistance of steel in aqueous medium. The ZMP and ZCPM decrease the corrosion rate of steel in $\mathrm{NaCl}$ solution by a factor of 2.15 and 3.50 , respectively.

\section{Acknowledgments}

The authors thank to CNPq, CNPq-CTPETRO (Proc. 460033/01-8), CAPES and FINEP (Proc. 22.01.0762.00), Brazil, for financial assistance.

\section{References}

1. Simpson, C.; Chemtech 1997, 27, 40.

2. Gerhard, A.; Bitiner, A.; J. Coat. Technol. 1986, 58, 59.

3. Del Amo, B.; Romagnoli, R.; Vetere, V. F.; Hernández, L. S.; Prog. Org. Coat. 1998, 33, 28.

4. Veleva, L.; Chin, J.; Del Amo, B.; Prog. Org. Coat. 1999, 36, 211.

5. Del Amo, B.; Romagnoli, R.; Vetere, V. F.; J. Appl. Electrochem. 1999, 29, 1401.

6. Vasconcelos, L. W.; Margarit, I. C. P.; Mattos, O. R.; Fragata, F. L.; Sombra, A. S. B.; Corros. Sci. 2001, 41, 2291.

7. Aramaki, K.; Corros. Sci. 2001, 43, 591. 
8. Deyá, M. C.; Blustein, G.; Romagnoli, R.; Del Amo, B.; Surf. Coat. Technol. 2002, 150, 133.

9. Del Amo, B.; Romagnoli, R.; Deyá, C.; González, J. A.; Prog. Org. Coat 2002, 45, 389.

10. Bethencourt, M.; Botana, F. J.; Marcos, M.; Osuna, R. M.; Sánchez-Amaya, J. M.; Prog. Org. Coat. 2003, 46, 280.

11. Zin, I. M.; Lyon, S. B.; Pokhmurskii, V. I.; Corros. Sci. 2003, 45, 777.

12. Beiro, M.; Caollazo, A.; Izquierdo, M.; Nóvoa, X. R.; Pérez, C.; Prog. Org. Coat. 1999, 36, 211.

13. Emsley, J.; The Elements, $3^{\text {th }}$ ed., Clarendon Press: Oxford, England, 1998, p.218.
14. El Abedin, S. Z.; J Appl. Electrochem. 2001, 31, 711

15. Pourbaix, M.; Atlas of Electrochemical Equilibrium in Aqueous Solution, Pergaman Press: New York, U.S.A.,1966.

16. Pourbaix, M.; Lectures on the Electrochemical Corrosion, Plenum Press: New York, U.S.A., 1973.

17. Jones, D. A.; Principles and Prevention of Corrosion, Maxweel Macmillan International Editions: Singapore, 1992.

18. Uhlig, H. H.; Revie, R. W.; Corrosion and Corrosion Control, An Introduction to Corrosion Science and Engineering, $3^{\text {th }}$ ed., John Wiley \& Sons: New York, U.S. A., 1985.

Received: August 19, 2004

Published on the web: May 18, 2005 